\title{
PARLAMENTARŲ INFORMACINÉS
}

ELGSENOS YPATUMAI: LIETUVOS

RESPUBLIKOS SEIMO NARIŲ ATVEJIS

\author{
Aurelija Vernickaité
}

Vilniaus universiteto Komunikacijos fakultetas, doktorante

Vilnius University Faculty of Communication, Ph. d. Candidate

Sauletekio al. 9, LT-10222 Vilnius

El. paštas aurelija.vernickaite@kf.stud.vu.lt

\section{Santrauka}

Informacijos vaidmuo ir įtaka politiniams sprendimams teoriniu požiūriu suvokiama ir interpretuojama gana skirtingai, tačiau jos reikalingumas ir svarba išlieka nepaneigiami. Parlamento narius galima vadinti vienais iš svarbiausiu informacijos vartotoju, nes nei politiniai sprendimai, nei politinè veikla, nei politika iš esmès negali büti atskirti nuo informacijos, todèl politiku kaip informacijos vartotoju elgsena reikalauja išskirtinio tyrejju dèmesio ir kruopščios analizès. Tokie tyrimai svarbūs ir aktualūs siekiant atskleisti ir suvokti parlamentaru informacinius poreikius, informacijos ieškos ir informacijos naudojimo priimant sprendimus ypatumus, taip pat tai leidžia numatyti praktines informacijos sklaidos ir aprūpinimo informacija tobulinimo galimybes parlamente, o tai yra ypač svarbu siekiant geresnio ir sklandesnio sprendimu priemimo istatymu leidybos institucijoje. Kol kas Lietuvoje galima pastebeiti tik užuomazgas moksliniu bandymu tirti Seimo nariu informacine elgsena. Šiame straipsnyje pristatomi rezultatai atlikto kokybinio tyrimo, kuriuo siekiama atskleisti Lietuvos Respublikos Seimo nariu informacines elgsenos ypatumus. Siekta ištirti, kaip parlamentarai suvokia informacijos vaidmeni politiniuose 
sprendimuose, kokie motyvai skatina parlamento narius ieškoti informacijos, kaip ir kur informacijos ieškoma, kaip Seimo nariai vertina gaunama informacija ir kaip ja naudoja (nenaudoja) priimdami sprendimus. Pateikiamas parlamento nariu požiūris ị informacijos sklaida parlamente ir sprendimu priemimo proceso informacinį aprüpinima, siekiant nurodyti galimas informacinio aprüpinimo tobulinimo galimybes.

Reikšminiai žodžiai: informacinè elgsena; informacijos ieška; informacinis aprūpinimas; Seimo nariai; sprendimų prièmimas; įstatymų leidyba.

\section{Ivadas}

Priimti sprendimus - viena iš pagrindinių parlamentarų veiklų, o sprendimų prièmimas, kaip procesas, neatsiejamas nuo informacijos ${ }^{1}$. Sprendimų prièmimo procesas gali būti apibrěžiamas kaip informacijos virtimas veiksmu, taip pabrèžiant informacijos svarbą šiame procese ${ }^{2}$. Informacijos ieška, sklaida ir jos naudojimas yra neatsiejami nuo sprendimo prièmimo ir traktuojami kaip viena iš sprendimo proceso dalių ${ }^{3}$. Nors požiūris ị informacijos vaidmenị ir naudą priimant politinius sprendimus gana skiriasi: vieni tyrẻjai teigia, kad informacija leidžia parlamento na-

1 Varnienè-Janssen, R., Vernickaitè, A. Parlamentarų informacinis aprūpinimas demokratijos pletros instrumentas. Parlamento studijos. Nr. 9 (2010), p. 31-50; Vernickaitè, A. Lietuvos Seimo narių informacijos poreikiai ir šaltiniai. Parlamento studijos. Nr. 13 (2012), p. 16-47; Blagnienè, R. The Information Analysis Department of Lithuanian Seimas. Parliamentary libraries and research services in Central and Eastern Europe: building more effective legislatures. München: K. G. Saur, 1998, p. 108-113; Blagnienè, R. Seimo narių informacinè elgsena sprendimų prièmimo procese. Informacijos mokslai. Nr. 63 (2013), p. 7-30.

2 Parsons, W. Viešoji politika. Vilnius: Eugrimas, 2001. 607 p.

3 Kingdon, J.W. Congressmen 's voting decisions. Ann Arbor: University of Michigan Press, 1989. 344 p.; Saunders, C., Jones, J.W. Temporal sequences in information acquisition for decision making: a focus on source and medium. The academy of management review. Vol. 15 (1990), p. 29-46. 
riams kaip tautos atstovams veiksmingiau dalyvauti politiniuose procesuose, užtikrinti sprendimų priëmimo demokratiškumą ir efektyviau prižiūrèti įtakingas ir stiprias vykdomosios valdžios institucijas ${ }^{4}$, todèl ịstatymų leidejjams reikia geresnio informacinio aprūpinimo ir būtina užtikrinti galimybę parlamento nariams laiku gauti patikimą ir kokybišką informaciją ${ }^{5}$; kiti tyrejjai mano priešingai - informacijos vaidmuo politikoje yra menkas, nes politikams reikia ne objektyvios informacijos, o tik tokios, kuri patvirtintų jų poziciją, informacija naudojama kaip retorinis įrankis ir tik tada, kai atitinka politikų nuomonę, o tą informaciją, kuri jų politinei pozicijai prieštarauja, politikai linkę ignoruoti ${ }^{6}$. Tačiau nors informacijos vaidmuo ir ittaka politikoje suvokiama ir interpretuojama skirtingai, jos svarbos ir reikalingumo politiniuose procesuose tai nepaneigia.

\section{Sprendimų prièmimas ir informacijos vaidmuo: skirtingų teorinių požiūrių ižvalgos}

Sprendimų prièmimo teorijos ir modeliai gana skirtingai aiškina ir interpretuoja informacijos vaidmeni priimant sprendimus ir tai, kaip

4 Peters, B.G., Barker, A. Governments, information, advice and policymaking. Advising West European governments: inquiries, expertise and public policy. Edinburgh: Edinburgh University Press, 1993, p. 1-36; Robinson, W., Hyde, J. Legislatures and information capabilities in emerging democratic nations: a framework for assessment. Parliamentary libraries and research services in Central and Eastern Europe. München: K. G. Saur, 1998, p. 1-25.

5 Bimber, B. Information as a factor in congressional politics. Legislative studies quarterly. Vol. 16 (1991), p. 585-605; Carey, J.M. Legislative organisation. The Oxford handbook or political institutions. Oxford: Oxford University Press, 2009; Cooper, J., Brady, D.W. Toward diachronic analysis of Congress. The American political science review. Vol. 75 (1981), p. 988-1006; Davidson, R.H., Oleszek, W.J. Congress and its members. Congressional quarterly books, 1997. 664 p.

6 Moynihan, D.P. Why and how do state governments adopt and implement "Managing for results" reforms? Journal of public administration research and theory. 2005, vol. 15, no. 2, p. 219-243; Moynihan, d.P. Goal-based learning and the future of performance management. Public administration review. Vol. 65, no. 2 (2005), p. 203-216. 
sprendimų priėmimo pobūdis nulemia informacinès elgsenos ypatumus: kaip ir kur informacijos ieškoma, kiek pastangų tam skiriama, kaip informacija vertinama ir naudojama.

Racionalumo teorija remiasi prielaida, kad sprendimų prièmejjas yra pajėgus visapusiškai išanalizuoti situaciją, turi pakankamai informacinių ir intelektinių išteklių veikti kuo racionaliau, žino visas galimas sprendimo prièmimo alternatyvas bei pasekmes ir yra pajègus pasiekti norimą geriausią, optimaliausią sprendimą ${ }^{7}$. Racionaliuoju požiūriu sprendimų priemėjas turi turèti teisingą, patikimą ir tikslią informaciją apie esamą situaciją, antra - jis turi turèti visą informaciją apie ateitị, tai yra kokios pasekmès gali būti prièmus vieną ar kitą sprendimą, trečia - jis turi turèti informacijos apie tai, kokiomis vertybèmis ir preferencijomis remtis pasirenkant tarp alternatyvų, kad būtų priimti objektyviai geriausi sprendimai ${ }^{8}$. Tačiau realybėje racionalus sprendimo prièmimas yra sunkiai igyvendinamas, nes jis reikalauja sunkiai pasiekiamų informacijos ieškos ir apdorojimo pajegumų 9 . Individo galimybes priimti racionalius sprendimus riboja jo kognityviniai gebejimai, intelektinis potencialas, patirtis, igūdžiai; sprendimų prièmimą veikia turimi laiko ir kiti, pavyzdžiui, materialiniai ištekliai ${ }^{10}$. Akcentuojama ir informacijos pertekliaus problema - ne informacijos trūkumas yra pagrindinè sprendimų prièmimo problema, o jos kiekis ${ }^{11}$.

Politikus siūloma suvokti kaip riboto racionalumo sąlygomis veikiančius sprendimų prièmèjus, kurie turi tikslus, tačiau veikia neapibrèžtame pasaulyje ir neturi išsamios informacijos, todèl dažniausiai

7 Hastie, R. Rational choice in an uncertain world: the psychology of judgement and decision making. Los Angeles: Sage Publications, 2010. 374 p.

8 Choo, C.W. The knowing organization: how organizations use information to construct meaning, create knowledge and make decisions. New York: Oxford University Press, 2006. 352 p.

9 Ten pat.

${ }^{10}$ Simon, H.A. Administraciné elgsena: sprendimų prièmimo procesų administracinèse organizacijose tyrimas. Vilnius: Knygiai, 2003. 405 p.

11 Ten pat. 
visų galimų alternatyvų neieško ir siekia tik „pakankamai gerų“ arba „patenkinamų“ (angl. satisficing) sprendimų ${ }^{12}$. Tokiu atveju sprendimų prièmèjai linkę taikyti tam tikras euristikas ${ }^{13}$ ir ieško būdų, kaip supaprastinti sprendimų prièmimą. Politikoje tokiu atveju elgesio taisykles gana aiškiai apibrèžia ideologinès nuostatos ir pažiūros arba partija ${ }^{14}$. Informacijos ieška taip pat atitinka minètą "patenkinamą“ strategiją, kai jos nebeieškoma radus tokios, kuri leidžia priimti „pakankamai gerą“" ar „patenkinamą“ sprendimą ${ }^{15}$.

Alternatyva racionaliam ir ribotai racionaliam sprendimų prièmimui yra vadinamasis „šiukšliaděžès“ modelis (angl. garbage can model), kuris dar ịvardijamas anarchiniu sprendimų prièmimu ${ }^{16}$. Toks sprendimų prièmimo modelis taikomas tada, kai nèra aiškūs ir žinomi nei tikslai, nei sprendimo būdai. Pagal „šiukšliadèžès“ modelị sprendimą sudaro problemos, sprendiniai, dalyviai ir pasirinkimo galimybès. Sprendiniai generuojami ne kaip atsakas ị problemas, bet kyla iš savanaudiškų sprendimų prièmẻjų interesų. Organizacijos įvardijamos kaip sprendinių rinkiniai, kai ieškoma problemų, kad būtų galima pasiūlyti savo sprendimus ${ }^{17}$. Tai nulemia, kad svarbios problemos gali būti ignoruojamos, nes nèra joms tinkamų sprendinių ${ }^{18}$. Tokiu atveju informacija turi menką ịtaką sprendimams: informacija, nors ir gaunama, nèra naudojama arba ji pasiekia jau prièmus sprendimą. Kita vertus, nors informacija gaunama ir nèra naudojama, jos prašoma vis daugiau - sprendimų prièmejjai patiria nuolatinị spaudimą rinkti in-

12 Kingdon, J.W. Politicians, self-interest and ideas. Reconsidering the democratic public. Pennsylvania State University Press, 1993, p. 73-89.

13 Tversky, A., Kahneman, D. The framing of decisions and the psychology of choice. Science. Vol. 211 (1981), p. 453-458.

${ }^{14}$ Kingdon, J.W. Politicians, self-interest and ideas...

15 Choo, C.W. The knowing organization...

16 Ten pat.

${ }^{17}$ Cohen, M., March, J.G., Olsen, P.J. A Garbage can model of organizational choice. Administrative science quarterly. Vol. 17 (1972), p. 1-25.

${ }^{18}$ Kingdon, J.W. Agendas, alternatives and public policies. New York: Harper Collins College Publishers, 1995. 253 p. 
formaciją tam, kad pademonstruotų siekiantys racionalumo arba norèdami pateisinti savo sprendimus ${ }^{19}$. Priimant sprendimus anarchiniu būdu informacijos ieška yra labiau atsitiktinè, nes problemos, atsitiktinai ar dèl tam tikrų asmeninių interesų, jau turi prie jų „prikabintus sprendimus“"20.

Kita alternatyva racionaliajam požiūriui - politinis sprendimų priemimas, kuris traktuojamas kaip derybų ir kompromisų tarp sprendimo prièmejų rezultatas. Kuo didesnis aplinkos neapibrèžtumas, tikslų prieštaringumas, priklausomybè nuo išteklių, tuo didesnè tikimybè, kad sprendimai bus priimami politiniu būdu ${ }^{21}$. Kai dalyvių preferencijos skiriasi, o tikslai prieštarauja vieni kitiems, sprendimų prièmimo gali būti siekiama taikant procedūrinị racionalumą (sukuriant galimybes suinteresuotoms grupèms formaliai dalyvauti sprendimų prièmimo procese ir išreikšti savo pozicijas) arba derybomis ir sudarant koalicijas ${ }^{22}$. Sprendimų priemimas traktuojamas kaip „politinis veiksmas“, kur pagrindinis vaidmuo tenka galiai, siejamai su socialinių veikejų gebejimais siekti tikslo darant poveiki kitiems socialiniams veikejjams ${ }^{23}$. Reikia pažymèti, kad šiuo atveju galia (angl. power) nèra prilyginama valdžiai (angl. authority), o yra siejama su vertybėmis ar įsitikinimais, kurie per tam tikrą laiką tampa pripažintais ir teisètais. Politinis sprendimo pobūdis lemia, kad informacijos ieška yra šališka ir selektyvi, pirmenybè teikiama tam tikriems informacijos šaltiniams, naudojama ta informacija, kuri pateisina ir patvirtina sprendimo prièmejjo poziciją ir nuomonę $e^{24}$ o informaciją, kuri tai pozicijai ar nuomonei prieštarauja, linkstama ignoruoti arba interpretuoti taip, kaip palanku sprendimų prièmejjui. Todèl po-

19 Ten pat.

${ }^{20}$ Choo, C.W. The knowing organization...

21 Ten pat.

22 Pfeffer, J. Power in organizations. Marshfield, Massachusetts: Pitman, 1981. 391 p.

23 Ten pat.

${ }^{24}$ Choo, C.W. The knowing organization... 
litiniuose sprendimuose informacijai tenka simbolinis vaidmuo, kai informacijos gavimas ir turejimas yra svarbiau nei realus jos naudojimas priimant sprendimus ${ }^{25}$, informacija tampa ne racionalaus sprendimo pagrindu, o labiau simboliniu ịrankiu siekiant įtikinti politinio proceso dalyvius ir stebėtojus iš šalies, kad sprendimai priimami tinkamai ir yra teisingi ${ }^{26}$.

Johnas Wellsas Kingdonas teigia, kad įstatymų leidejjams būdinga "probleminë“ informacijos ieška (angl. problemistic search), kai dèl priimamų sprendimų gausos informacijos ieškoma ir ji analizuojama tik tais atvejais, kai susiduriama su tam tikromis problemomis priimant sprendimus, pavyzdžiui, kai sprendimai yra kontroversiški, ideologiškai jautrūs, susiduriama su nauja ar nežinoma sprendimo situacija ${ }^{27}$. Jeigu, politiko suvokimu, priimamas sprendimas (balsuojama) dèl svarbaus ịstatymo projekto (svarbumą politikai sieja su sprendimais, kurie susiję su jų rinkejjų interesais, žiniasklaidos plačiai aptariamomis temomis ir kt.), jis labiau linkęs visapusiškiau ieškoti informacijos (angl. comprehensive search), kitais atvejais įstatymų leidejai linkę informacijos ieškoti paviršutiniškai (angl. perfunctory search) ${ }^{28}$.

${ }^{25}$ Feldman, M.S., March, J.G. Information in organizations as sygnal and symbol. Administrative science quarterly. Vol. 26 (1981), p. 171-186; Sager, T., Ravlum, I. The political relevance of planners' analysis: the case of a parliamentary standing committee. Planning theory. 2005, vol. 4 (33), p. 33-65.

${ }^{26}$ Meyer, J.W., Rowan, B. Institutionalized organizations: formal structure as myth and ceremony. The American journal of sociology. 1977, vol. 83, p. 340-363; Feldman, M.S., March, J.G. Information in organizations as sygnal and symbol...

${ }^{27}$ Kingdon, J.W. Congressmen's voting decisions...; Cyert, R.M., March, J.G. A behavioral theory of the firm. N. J. Prentice-Hall, 1963, p. 67-82.

${ }_{28}$ Zadoorian, J. The informed legislator: a theory of political information search. Doctoral dissertation. University at Albany, State University of New York, 2004. $171 \mathrm{p}$. 


\section{Lietuvos Respublikos Seimo narių informacinès elgsenos ypatumai: empirinis tyrimas}

Atliktu kokybiniu tyrimu siekiama atskleisti parlamentarų informacinès elgsenos ypatumus priimant sprendimus. Kadangi analizuojama individuali parlamentaro informacinè elgsena, sprendimų prièmimas yra siejamas su parlamentaro individualiu veiksmu - apsisprendimu (pasirinkimu) balsuojant dèl ịstatymo. Sprendimų prièmimas traktuojamas kaip situacija, motyvuojanti ir lemianti parlamentaro informacinę elgseną. Straipsnyje pasitelkiama gana plati informacinės elgsenos apibrèžtis. Parlamentarų informacinè elgsena apibrèžiama kaip visuma veiksmų, prasidedančių nuo informacinių poreikių atsiradimo ir apimančių informacijos iešką (vykdomą politikų tiesiogiai arba per tarpininkus) ívairiuose informacijos šaltiniuose ir tos informacijos panaudojimą sprendimams priimti. Parlamentarų informacinė elgsena apibūdinama ir kaip tikslinè (aktyvi), ir kaip pasyvi veikla, kai informacija parlamentarą pasiekia nededant pastangų, jis aprūpinamas informacija tikslingai ar sąmoningai jos neieškant, nesikreipiant, neišreiškus poreikio arba atsitiktinai.

Kokybinio tyrimo tikslas - atskleisti Lietuvos Respublikos Seimo narių informacinès elgsenos ypatumus priimant sprendimus.

Tikslui pasiekti keliami šie pagrindiniai uždaviniai:

1. atskleisti, kaip parlamento nariai apsisprendžia priimdami sprendimus (balsuodami) ir koks vaidmuo, parlamentarų požiūriu, šiame procese tenka informacijai;

2. išaiškinti pagrindinius motyvus, skatinančius parlamento narius ieškoti informacijos priimant sprendimus;

3. nustatyti, kaip parlamento nariai vertina ir naudoja gautą informaciją priimdami sprendimus;

4. nustatyti, kokių kliuvinių, susijusių su sprendimams priimti reikalingos informacijos gavimu ir naudojimu, parlamento nariams iškyla. 
Kokybiniam tyrimui atlikti pasirinktas individualusis interviu, nes jis laikomas tinkamu metodu individo požiūriui ir nuomonei apie nagrinèjamą problemą ištirti, atskleisti individualią sprendimo prièmèjo patirtị konkrečiose sprendimų prièmimo situacijose, patiems tyrimo dalyviams nustatyti svarbiausius nagrinejjamos temos probleminius aspektus ${ }^{29}$.

Individualaus pusiau struktūrinio interviu metu respondentui pateikiami atviri klausimai. Norint atskleisti ir pažinti individo informacinę elgseną, turi būti žinomos jo patirtys priimant konkrečius sprendimus, todèl respondentams buvo pateikiami ne tik bendro pobūdžio klausimai apie nagrinėjamą reiškinį, bet buvo prašoma prisiminti tam tikras konkrečias situacijas (šiuo atveju - balsuojant dèl ịstatymų) ir per jas atskleisti elgsenos ypatumus. Interviu schemą sudare du esminiai klausimų blokai: pirmasis - bendrieji klausimai apie sprendimų prièmimą parlamente ir kaip Seimo narys priima sprendimą balsuoti vienu ar kitu atveju, siekiant atskleisti, kokie veiksniai lemia sprendimų priemimą ir koks vaidmuo šiame procese tenka informacijai, taip pat nustatyti pagrindinius motyvus, lemiančius politikų poreikį ieškoti ir analizuoti informaciją. Antrasis blokas - klausimai apie tai, kaip parlamento nariai ieškojo informacijos konkrečiose sprendimų priemimo situacijose, kokiais informacijos šaltiniais naudojosi ir kodèl, kaip vertino gautą informaciją ir ją naudojo (nenaudojo) priimdami sprendimus. Tyrimo dalyvių buvo prašoma prisiminti skirtingas sprendimų prièmimo situacijas $^{30}$, kai buvo balsuojama dèl ịstatymo, kuris (1), respondento suvokimu, yra svarbus / aktualus ir kuris (c2), respondento suvokimu, yra rutininis / formalus. Interviu klausimai buvo formuluojami taip, kad suteiktų galimybę respondentams laisvai išreikšti savo mintis. Prireikus klausimų eiliškumas buvo keičiamas, užduodami anksčiau nenumatyti klausimai, kurie leisdavo gauti svarbios papildomos informacijos, susijusios su tiriamąja problema.

${ }^{29}$ Kvale, S. Doing interviews. Los Angeles: Sage Publications, 2013. 157 p.

${ }^{30}$ Zadoorian, J. The informed legislator...; Kingdon, J.W. Congressmen's voting decisions... 
Tyrimo imtis. Tyrimo metu apklausta 19 Seimo narių. Duomenų rinkimas tęsési tol, kol pavyko pasiekti tam tikrą prisotinimo lygit, tai yra, kai gaunama informacija pradejo kartotis ir tolimesni interviu suteikè vis mažiau naujų duomenų ir informacijos ${ }^{31}$. Taikyta tiksliné atranka, kai informantai buvo atrenkami apgalvotai, norint gauti svarbios informacijos ir siekiant pateikiamų duomenų informatyvumo. Atrenkant informantus buvo laikomasi principo, kad ị tyrimo imtị patektų skirtingų lyčių ir amžiaus parlamentarai, užimantys pareigas (parlamente arba frakcijoje / partijoje) ir jų neužimantys, turintys skirtingos parlamentinès veiklos patirties, išrinkti skirtingose apygardose, atstovaujantys skirtingoms parlamentinèms pozicijoms (pozicijai / opozicijai) ir frakcijoms / partijoms.

Tyrimo dalyvių apibūdinimas pagal demografines ir sociopolitines charakteristikas: lyti (8 moterys ir 11 vyrų); amžių (iki 50 metų - 9, daugiau kaip 50 metu - 10); parlamentinio darbo patirti (viena kadencija - 8, dvi ir daugiau kadencijų - 11); užimamas pareigas (komiteto / komisijos pirmininkas ar pirmininko pavaduotojas - 6, frakcijos seniūnas ar seniūno pavaduotojas - 5, neužimantys pareigų - 8); pasiskirstymą pagal parlamentinę poziciją (opozicija - 9, pozicija - 10); išrinkimo apygardą (daugiamandatè - 11, vienmandatè - 8).

Interviu rinktas per du etapus: pirmąkart interviu imtas $2012 \mathrm{~m}$. birželio mėn., antrą - 2013 m. rugsèjo-spalio mėn. Interviu trukmè varijavo nuo $14 \mathrm{~min}$. iki 1 val. $22 \mathrm{~min}$.

Duomenų rinkimas ir analizè. Individualaus interviu metu gauti duomenys, siekiant užtikrinti tyrimo pagrịstumą ir patikimumą, buvo fiksuojami diktofonu, tekstas - transkribuotas. Gauti duomenys išanalizuoti taikant kokybinès turinio analizès metodą, kuris pasižymi prasminių vienetų nustatymu, vertinimu ir interpretacija. Duomenys buvo kategorizuojami, tai yra tekstai suskirstyti ị prasminius vienetus -

${ }^{31}$ Kvale, S. Doing interviews...; Hood, J.C. Orthodoxy vs. power: the defining traits of grounded theory. The Sage handbook of grounded theory. Los Angeles: Sage Publications, 2007, p. 151-164. 
kategorijas, prireikus - ir ị subkategorijas, atspindinčias respondentų patirtị ir požiūrį, susijusius su kokybinio tyrimo uždaviniais.

Tyrimo etika. Tyrimo dalyvių tapatybès neatskleidžiamos. Analizuojant tyrimo duomenis iš cituojamų tekstų buvo pašalinti vardai, pavardès, tam tikrais atvejais ir užimamos pareigos - tai, kas galètų leisti identifikuoti tyrimo dalyvius. Tyrimo dalyvių buvo klausiama, ar jie sutinka, kad interviu būtų ịrašomi. Visi tyrimo dalyviai sutiko.

\section{Seimo narių informacinès elgsenos ypatumai: kokybinio tyrimo duomenų analizè}

Sprendimų prièmimą lemiantys veiksniai ir informacijos vaidmuo priimant sprendimus parlamentaru požiūriu. Analizuojant interviu duomenis išskirtos 7 kokybinès kategorijos - veiksniai ir aplinkybès, kurie, tiriamųjų nuomone, veikia ir daro ịtaką sprendimų prièmimui parlamente (1 lentelè).

\section{1 lentelè. Sprendimų prièmimą parlamente lemiantys veiksniai}

\begin{tabular}{|c|}
\hline Kategorija \\
\hline Laiko trūkumas \\
\hline Darbotvarkės perkrova \\
\hline Skirtingi ir prieštaraujantys tikslai \\
\hline Daug veikèjų \\
\hline Priklausomybė nuo kitų veikèjų \\
\hline Sprendimų prièmimas neapibrěžtumo sąlygomis \\
\hline Proceso organizavimas \\
\hline
\end{tabular}

Vienos iš dažniausiai politikų minètų aplinkybių, veikiančių sprendimų prièmimą - laiko trūkumas ir darbotvarkès perkrova („,istatymų daug, o laiko per mažai“; „galiu priminti naktinius istatymus mokestinius ir tuos pakeitimus, kur buvo skubama ir padarytos baisingos klaidos“; „del sprendžiamu problemu gausos ir ìvairoves, parlamentarams tiesiog žmo- 
giškai pritrūksta išgaliu įsigilinti i kiekvieną). Parlamentarai atkreipia dėmesį, kad istatymų leidybos procesas Lietuvoje vis dar labiau orientuotas $\mathfrak{i}$ kiekybinius, o ne kokybinius parametrus, o parlamento darbą vienas tiriamasis prilygino „fabriko“ darbui. Minètos aplinkybès - laiko trūkumas ir darbotvarkès perkrova, taip pat parlamentarų požiūris ir gebejjimai, anot tiriamųjų, dažnai nulemia sprendimų priėmimo parlamente „paviršutiniškumą“, išsamesnès analizès trūkumą, „neįsigilinimą“ i priimamus sprendimus („sprendimu priemime yra suprantama, kad tu vis tiek visais klausimais labai samoningai negali balsuot, $<\ldots>$ neturi nei laiko, nei galimybiu i visus klausimus isigilinti“; „dažnu atveju, manau, Seimo nariai balsuoja paviršutiniškai susidarę informacija“; „pas mus įstatymu dar turbūt leidybos yra ta stadija, kuri pakankamai vyksta greitai ir be didesnés analizés"). Parlamentarai teigia, kad priimant sprendimus parlamente dažnai susiduriama su skirtingais ir tarpusavyje prieštaraujančiais tikslais, skirtingais interesais, kurie dažnai apsunkina sprendimų priemimą („ne tik frakcija, bet ir kiekvienas Seimo narys turi savo nuomones, tikslus, pažiūras“; „parlamente tiek daug požiūrių ir nuomoniü, kad kartais labai sunku suprasti, kas už ko slepiasi“). Sprendimų prièmimas parlamente, respondentų nuomone, išsiskiria ir tuo, kad jame dalyvauja daug dalyvių - ne tik parlamentarai ar parlamentinès grupès, bet ir Vyriausybė bei kitos vykdomosios valdžios institucijos, biurokratinis aparatas, interesų grupès, rinkejjai. Parlamentarai teigia, kad didelis veikèjų skaičius lemia tai, jog sprendimų prièmimas parlamente yra „labai gremėzdiškas procesas“" „ir Vyriausybe, ir Prezidente, ir lobistai, ir kiekvienas traukia paklode i save, o sprendima priimi tai tu“. Kitas politikas atkreipè dèmesị $i$ tai, kad „yra daug žmoniu, kurie dalyvauja sprendimo priemime, tačiau né vienas ju realiai neatsako pilnai, - ar materialiai, ar dar kažkaip“. Kai kurie respondentai pastebejjo, kad svarbius sprendimus tenka priimti esant neapibrèžtumo sąlygoms („tai ir dabar svarstom, kad ir Venckienès atveji: $<\ldots .>$ kaip reikejjo Statuta parašyt, kad ir tokius atvejus numatyt, kad koks Seimo narys pabėgs kažkur ir slapstysis su tokiu pagrindu kaip čia ir atsitikę). 
Anksčiau minètus veiksnius ir aplinkybes informantai dažniausiai išskiria kaip tokius, kurie sprendimų priemimą politikoje apsunkina ir daro sudètingą, nors kai kurie tiriamieji atkreipé dėmesį, kad sprendimų priemimas parlamente yra tinkamai organizuotas („pats procesas yra organizuotas pakankamai neblogai ir to laiko isigilinti tikrai pakanka“, „normalus tas procesas ir mane viskas tenkina“).

Tyrimo metu buvo siekiama išsiaiškinti, kaip parlamentarai priima sprendimus balsuodami dèl įstatymų ir koks vaidmuo, jų suvokimu, tenka informacijai šiame procese. Analizuojant informacijos vaidmeni priimant sprendimus išskirtos trys kokybinès kategorijos (2 lentelè).

\section{2 lentelè. Suvokiamas informacijos vaidmuo priimant sprendimus}

\begin{tabular}{|c|c|}
\hline Kategorija & Subkategorija \\
\hline Svarbiausias & $\begin{array}{l}\text { "pagrindinis“" } \\
\text { „informacija svarbiausia“ } \\
\text { „absoliutus“ } \\
\text { „besąlygiškkas“ } \\
\text { „esminis“" } \\
\text { „kertinis“ }\end{array}$ \\
\hline Simbolinis & $\begin{array}{l}\text { „informacija politizuojama“ } \\
\text { „informacija neišsprendžia vertybinių } \\
\text { konfliktų“ }\end{array}$ \\
\hline Nèra svarbiausias & „ne informacija svarbiausia“ \\
\hline
\end{tabular}

Tyrimo duomenų analizė atskleidè, kad dauguma tiriamųjų informacijos vaidmenị ir svarbą priimant sprendimus vertina kaip „pagrindinį“, „absoliutų“, „besąlygišką“, „esminį, „kertinį“ („be informacijos <...> tai tiesiog neimanoma priimti sprendimo“; „informacijos vaidmuo yra absoliutus - tai yra, jisai būtinas, nes jeigu tu nesi įsigilinęs i klausima, tai tu balsuoji, vadovaudamasis turbūt šeštu pojūčiu“; „aš esu šventai įsitikinus, kad vis delto kuo daugiau turi informacijos, tuo sprendimai yra teisinges$\left.n i^{\prime \prime}\right)$. Kai kurie politikai buvo linkę akcentuoti tai, kad priimant politinius sprendimus informacija yra kaip politinis įrankis ir ne ji nulemia sprendimus (,tikrai ne informacija politikoje svarbiausia. Ne. <...> Kai kuriais 
atvejais interesai, kai kuriais atvejais - emocijos, kai kuriais atvejais - populistiniai pažadai, duoti rinkejjams“; „tai ta informacija politizuojama ir naudojama tam, kad ịtikintum, įrodytum savo tiesa").

Atlikus turinio analizę išskirti tam tikri parlamentarų apsisprendimą lemiantys veiksniai. Jie suskirstyti i 8 kokybines kategorijas (3 lentelè).

\section{3 lentelè. Parlamentarų apsisprendimą lemiantys veiksniai}

\begin{tabular}{|c|}
\hline Kategorija \\
\hline Partijos programa \\
\hline Frakcijos / partijos pozicija ir jos lyderio vaidmuo \\
\hline Frakcijos drausmè \\
\hline Nebalsuoja \\
\hline Emocijos, „šeštas pojūtis“ \\
\hline Patirtis \\
\hline Vertybès, sąžinè \\
\hline Rinkèjų interesai \\
\hline
\end{tabular}

Tiriamieji teigè, kad jų apsisprendimą, ypač kai priimamas svarbus sprendimas vertybiniu ir ideologiniu požiūriais, nulemia partijos programinès nuostatos. Tai liudija šie teiginiai: „galvoje yra vis tiek mūsu programos, mūsu ideologijos principai“; „mes turime savo partijos rinkimine programa ir šiuo atveju yra tie klausimai, kurie yra, na, vertybiniai, tai visada pirmiausia kaip trafareta užsidedi savo rinkimine programa“; „jeigu yra prieštaraujantis programai dalykas, tai natūralu, kad tu tada iškart formuoji pozicija nepritarti“; „yra frakcijos, <...> yra partijos, yra partiju programos - ju reikia laikytis“. Parlamentarai teigè, kad jų apsisprendimą dažnai nulemia ir frakcijos ar partijos suformuota pozicija bei jos lyderių nuomonė („devyniasdešimt atveju iš šimto niekaip nesu informuotas, nesiekiu būt informuotas ir balsuoju <...> taip, kaip nusprende frakcija“; "prokuroro nuemimo klausimu ir partija, ir frakcija turi labai aiškią poziciją, kad čia yra, tarkim, politikavimas ir panašūs dalykai ir šitoj vietoj jau reikia to susitelkimo balsuojant“; „jeigu vertinant pirmaja 
mano kadencija, tai buvo santykiai tokie, kad yra stipri frakcija, ganètinai stipri frakcija, ir ji turi tam tikra i taka priimant sprendimus"). Parlamentarai minejo, kad frakcijose egzistuoja drausmès taisyklès, kurioms jie linkę paklusti priimdami sprendimus („,buvo pasakyta „reikia“; „kai tai yra aiškiame santykyje su mūsu ginamomis vertybèmis <...> būna toks jau sutarimas tvirtas, dažnai su privalomu balsavimu“; „aš esu už tą bendra drausmę, nes manau, kad frakcijos bendri sprendimai padeda išlaikyti veida tam tikra irgi politinés jegos"). Kai kurie kalbinti politikai teigè, kad jeigu „nežino“, mano neturintys pakankamai informacijos sprendimui priimti arba informacija yra prieštaringa, jie linkę visai nedalyvauti priimant sprendimus („jeigu taip būna ir aš tikrai nežinau, kaip balsuot, aš geriau tada nebalsuoju“; "pavyzdžiui, dèl skalūnu tu visu <...> iš tikrujų labai yra sunku apsispręsti ir nuspręsti, kaip ten turètu būti, ir aš nedalyvavau balsavime"). Tyrimas atskleidè, kad politikai linkę priimti sprendimus vadovaudamiesi savo ankstesne balsavimo, politinio darbo arba asmenine patirtimi („aš gal nemažai pasikliauju ir savo intuicija, ir patirtim“; „turiu politines patirties, tai man kartais lengviau“; „kartais gyvenimiška patirtis man reiškia kur kas daugiau nei mokslininkų straipsniai"). Kai kurie tiriamieji atkreipe dèmesị, kad priimant politinius sprendimus tam tikras vaidmuo tenka ir emocijoms, ypač tuomet, kai priimamas kontroversinis sprendimas arba Seimo nariui trūksta kompetencijos: „emocijos čia daug lemia, ypač jeigu Seimo narys ne visai yra kompetentingas toje srityje“; "pavyzdžiui, „Chevrono“ atvejis, skalūninès dujos - tai emocinis momentas“; „esam maža valstybè, tai sergam mažos valstybès ligomis, kad kompetencijos kai kuriose srityse pas mus tiesiog nèra, <...> tada jau pradedi vadovautis tokiu šeštu pojūčiu"). Parlamentarai tvirtina, kad politiniai sprendimai taip pat yra lemiami asmeninių politikų vertybių, nuostatų, sąžinès („man pasisekè dèl to, kad antra ir trečia kadencija aš dirbu Mišrioje Seimo nariu grupëje <...> ir niekas niekam nediktuoja sprendima priimi pats, remiesi savo protu, savo sažine, savo vertybemis“; „svarbiais klausimais aš balsuoju taip, kaip man liepia sąžine‘). Kai kurie informantai teigè, kad priimdami sprendimus jie atsižvelgia ị savo rinkè- 
jų ir savo rinkimų apygardos interesus („mano apsisprendima formuoja mano rinkejju norai ir situacija mano rinkimu apygardoj“; „dalis tikrai priima sprendimus tokius, kokius nori matyti rinkejai“; „populistinius sprendimus priima tam, kad įtiktu rinkejams").

Informacijos, susijusios su sprendimų prièmimu, ieška ir informacijos šaltinių naudojimas. Parlamentarų buvo prašoma prisiminti realias sprendimų prièmimo situacijas siekiant išsiaiškinti, kas lemia, kiek pastangu parlamentarai skiria informacijai, susijusiai su priimamu sprendimu, rasti ir suvokti; kaip politikai informacijos ieškojo, kokiais informacijos šaltiniais naudojasi priimdami sprendimą ir kodèl. Tyrimo duomenų analizė išryškino reikšmingus veiksnius ir aplinkybes, kurie motyvuoja parlamentarus ieškoti ir issigilinti i sprendimo prièmimui reikalingą informaciją. Šie veiksniai pateikti 4 lentelejje ir suskirstyti ị 9 kokybines kategorijas.

4 lentele. Parlamentarų informacijos iešką motyvuojantys veiksniai

\begin{tabular}{|c|}
\hline Kategorija \\
\hline Sprendimo svarbumas / aktualumas \\
\hline Sprendimo kontroversiškumas \\
\hline Domėjimasis tema, problemos išmanymas ir pradinis žinojimas \\
\hline Pareigos ir specializacija \\
\hline Istatymo rengimas \\
\hline Netikrumas \\
\hline Galimybė daryti įtaką \\
\hline Politinės nuostatos \\
\hline Patirtis \\
\hline
\end{tabular}

Vienas iš dažniausiai tiriamųjų minimų motyvų, skatinančių parlamentarus ieškoti informacijos, suvokti ir ịsigilinti ị gaunamą informaciją, yra sprendimo aktualumas ir svarbumas: sprendimas sukelia visuomenès susidomėjimą, yra aktualus didesnei visuomenès daliai, „rezonansinis“, „karštas“, sulaukia žiniasklaidos dèmesio ar kitų gru- 
pių išankstinès reakcijos („kas sukelia ažiotažq didesnį“; „jeigu karštas sprendimas, tai yra juo susidomi žmonès, laikraščiai, televizija, tai ir tu domiesi, giliniesi“; „visuomenès susidomèjimas“; „rezonansinè problema“; „žiniasklaidinis fonas, būna, sakykim, kažkokie rezonansiniai klausimai, kurie kažkiek tai, matyt, iš anksto tau pradeda formuoti pozicija“). Dar vienas politikų informacijos ieškos elgseną motyvuojančių veiksnių - sprendimo kontroversiškumas, nuomonių skirtumai ir nesutarimai dèl sprendžiamos problemos („būna tokiu kontroversišku klausimu, kur nuomonés išsiskiria, tai tais atvejais tada ieškai informacijos“; „jeigu istatymas kelia daug priešpriešu ir jei tu galvoji pasisakyt“; „skalūnų duju klausimas kèle daug prieštaru, todèl ị ši klausima labai atsakingai žiūrèjau“; „kai nuomonių skirtumai ir nesutarimai labai ryškūs, tada tu tikrai ieškai informacijos"). Politikai linkę skirti daugiau laiko ir pastangų susipažinti su gaunama informacija ir ieškoti papildomos informacijos, jeigu priimamas sprendimas jiems yra asmeniškai iddomus, problema ir sritis žinoma bei aktuali („jei tau neįdomi tema, tu tada žiūri atsainiau, jei ịdomi - giliniesi“; „jeigu tau iš tikruju rūpi tas projektas, yra iš tos srities, kur tu kažkiek angažuojiesi“; „jeigu tu ta tema domiesi, tai tu stengiesi perskaityti visa gaunama informacija“; „informacijos paieškos apimtį, kokybiškumą, giluma lemia patirtis toje pačioje srityje, jos žinojimas"). Dauguma tiriamųjų atkreipè dėmesĭ, kad jų informacijos ieškos elgsenai didelę ịtaką daro užimamos pareigos (pavyzdžiui, vadovavimas komitetui (komisijai), pareigos frakcijoje (partijoje) bei priklausomybė pagal specializaciją tam tikram komitetui, pavesta atsakomybė už tam tikrą sritị frakcijoje (partijoje) („būnant komiteto pirmininku ar frakcijos vadovu tu tiesiog priverstas ieškoti ir turèti daugiau informacijos“; „mane verčia ir pareigos ieškoti informacijos“; „neabejotinai lemia klausimu ratas, kuriuos ir partija ipareigoja tave spręsti, ir komitetas, kuriame tu esi“; "priklauso, koki vaidmenị aš atlieku"). Tiriamieji taip pat teigè, kad jie daugiau laiko ir pastangų skiria informacijai rasti, ịsigilinti ị ją, jeigu yra atsakingi už istatymo projekto rengimą („savo teikiamam projektui, žinoma, tada 
skiri patị didžiausią dèmesį“; „jeigu aš rengiu įstatymo projekta, aš tada atitinkamai dirbu jau sistemingai aiškindamasi, ieškodama informacijos, gilindamasi i ją").

Tyrimo duomenų analizè leidžia daryti prielaidą, kad didesnę parlamentinio darbo patirtį turintys parlamentarai labiau linkę pasikliauti patirtimi priimdami sprendimus ir tam tikrais atvejais skiria mažiau pastangų informacijos ieškai bei jos analizei nei mažesnę patirtị turintys parlamentarai, kurie, manytina, turi prieigą prie mažiau informacijos šaltinių, ilgiau užtrunka, kad informaciją rastų bei įsitikintų, ar ta informacija patikima („esant trečioj kadencijoj ta informacija pats jau daug lengviau susirandi, nes žinai, kur jos ieškoti“; „iš karto atėjęs naujas Seimo narys, jisai skaito visa informacija, o informacijos yra neimanomai“; „kodèl praradau akis? Todèl, kad pirmoj kadencijoj vis nešdavausi popierinius variantus ir iki vidurnakčio skaitydavau kiekviena ìstatyma. $<\ldots>$ dabar patirtis jau leidžia lengviau apsispręsti“; „naujas žmogus, Seimo narys šiuo atveju, jisai pradžioj net nežino, kur ieškot ir net ko ieškoti").

Turinio analizè atskleidè, kad tam tikrus informacijos šaltinius tiriamieji linkę vertinti kaip reikšmingesnius ir svarbesnius priimant sprendimus, tačiau vienareikšmiškai ịvardyti, kad vieni šaltiniai daro didesnę ittaką nei kiti, nebūtų galima. Tyrimo duomenys rodo, kad priimant tą patị sprendimą parlamentarams svarbūs ir lemiantys gali būti visiškai skirtingi informacijos šaltiniai. Pavyzdžiui, priimant sprendimą dèl skalūnų dujų ìstatymų, vienas respondentas teigè, kad „vadovaujuosi savo intuicija, savo žiniom ir žmoniu nuomone ir aš balsavau prieš skalūnus“, tuo metu kitas parlamentaras akcentavo, kad balsavo už įstatymą, nes priimdamas sprendimą rèmési „fiziku, mokslininku nuomone, pasitikédamas tam tikrais Europos Sajungos standartais“. Kitu atveju, balsuojant dèl valstybès tarnautojų atlyginimo atkūrimo, vienas parlamentaras teigè, kad svarbiausi informacijos šaltiniai apsisprendžiant, kaip balsuoti, buvo „asmenine patirtis, sukaupta dirbant vykdomaji darba Vyriausybeje keturis metus ir žinant, iš tikrujų, labai tą situacija realiai, <...> Finansų 
ministerijos skaičiavimai ir <...> mūsu žiniasklaidos fonas", savo ruožtu kitas parlamentaras teigè, kad jam svarbiausias informacijos šaltinis buvo „eilinis valstybès tarnautojas, kuris negauna nei dešimt, nei penkiolikos, nei dvidešimt tūkstančiu - gauna du tūkstančius popieriuj“.

Remiantis duomenų turinio analize išskirtos 2 informacijos šaltinių kategorijos, kurios dar suskaidytos ị subkategorijas (5 lentelè). Šioje lenteleje išvardyti visi informacijos šaltiniai, kuriuos parlamentarai bent kartą paminėjo kalbėdami apie realias sprendimų prièmimo situacijas ir informacijos iešką priimamų sprendimų kontekste.

5 lentelè. Informacijos šaltinių naudojimas priimant sprendimas

\begin{tabular}{|c|c|}
\hline Kategorija & Subkategorija \\
\hline \multirow{7}{*}{ Vidiniai } & Frakcijos / partijos kolegos \\
\hline & Komitetai \\
\hline & Frakcijos / partijos ekspertų grupès, referentai \\
\hline & Asmeniniai padejjèjai / patarèjai \\
\hline & Seimo kanceliarijos Parlamentinių tyrimų departamentas \\
\hline & Seimo skaitykla \\
\hline & Seimo kanceliarijos Teisès departamentas \\
\hline \multirow{10}{*}{ Išoriniai } & Vykdomosios valdžios institucijos \\
\hline & Interesų grupès \\
\hline & Mokslinès institucijos, analitiniai centrai \\
\hline & Rinkejjai \\
\hline & Bibliotekos \\
\hline & Valstybinès institucijos \\
\hline & Europos Parlamento frakcijos \\
\hline & Internetas, virtualūs socialiniai tinklai \\
\hline & Žiniasklaida \\
\hline & Buvę kolegos, pažistami, artimieji \\
\hline
\end{tabular}

Frakcijos (partijos) kolegos tiriamųjų i̇vardijami kaip vieni svarbiausių informacijos šaltinių („Seimo nariai iš tikrujų daugiausia tik $j$ savo sriti gilinasi, <...> o kiti klausimai, kurie yra jau iš tokiu ne tokių 
artimu sričiu - tai pasitiki savo kolegomis“; „mes remiamés daugiau $i$ žmones, kurie dirba komitetuose“; „aš nesiangažuoju užsienio politikoj $<\ldots>$, tai sau fiksuoju, kad frakcijoj yra kiti žmonès, aš pasikliausiu, kq jie ten išsiaiškins, kq pasiūlys, pasikliausiu ju atsakomybe"). Frakcijos kolegos tiriamųų suvokiami kaip patikimas informacijos šaltinis ir tai nulemia jo svarbą („pasitikiu ir balsuoju, kaip kolega patare““; „aš dažnai linkusi bütent ir pasitikèti tuo, ka kompetentingas mano kolega"). Tiesa, ne visi kolegos traktuojami kaip vienodai patikimi („vienais labiau tiki, kitais - mažiau, bet yra jeigu žmogus autoritetas $<\ldots>$ - tai ir pasitiki“; „visais vienodai nepasitikiu, bet dauguma pasitikiu ir balsuoju, kaip man pataria“). Tyrimo metu išryškejjo tendencija, kad tiriamieji labiau linkę pasitikèti ir remtis tais kolegomis, kurie turi daugiau patirties („tie, kurie jau tris, keturias ar penkias, o yra ir tokiu, kur šešias kadencijas Seime dirba, tai vis tik jie turi svaresni žodį“; "galutinai apsisprendi tai klausant patyrusių mūsu frakcijos kolegu nuomonès"), taip pat užimančiais aukštesnes pareigas („daugiau kreipi demesị ị tuos, kurie daugiau patyrę arba užima pareigas“; „kai tu esi naujokas, tai kreipiesi i patyrusius patarimo"). Frakcijos kolegos kaip informacijos šaltinis vertinamas dèl to, kad yra lengvai prieinamas sprendimo metu („tu čia pat, posèdžiu saleje, gali prieiti prie kolegos“; „aš tikrai pasitikiu savo kolega, kuris yra dirbęs, žino gerai tą sriti, gilinasi i ją, ir jis man kompetentingai paaiškina ir tai yra ženkliai greičiau gaunama informacija"), galintis suteikti svarbios ir aktualios informacijos („komitetuose kolegos išklauso skirtingas nuomones, skirtingas pozicijas, issigilina j klausimus ir tada tau referuoja pagrindinius dalykus"). Kai priimamas sprendimas, susijęs su, kaip tiriamieji ịvardija, „techniniais“, „rutininiais“, „formaliaisiais“, „neesminiais“ įstatymų pakeitimais, jie linkę besąlygiškai remtis kolegomis kaip informacijos šaltiniu apsispręsdami, kaip balsuoti. Tai liudija tokie teiginiai: „kartais aklai tikrai pasitiki tuom žmogum, kuris dirba Ekonomikos komitete, kuris gilinosi“; „aš buvau toks užsiemęs darbais savo komitete, kad tik atèjau i posédžiu salę kelioms minutèms, paklausiau frakcijos kolegos, kaip balsuoti, užbalsavau ir vél išèjau“. 
Kitas tiriamųjų vienas iš dažniausiai minètų informacijos šaltinių Vyriausybe ir vykdomosios valdžios institucijos („būnant valdančioje daugumoje tu beveik aklai pasikliauji Vyriausybès nuomone“; „jeigu teikiama nuo Vyriausybès, tai automatiškai galbūt patikimiau negu nuo opozicijos"). Tiriamieji vykdomosios valdžios, valstybinių institucijų teikiamą informaciją linkę vertinti kaip svarbią ir patikimą dèl ekspertinių ir analitinių gebejimų („informacija laikau pakankamai objektyvia ir patikima“; „virš devyniasdešimt procentu, aš sakyčiau, ju išvados yra pakankamai gerai apgalvotos ir pagristos“; „ministerijos turi po kelis šimtus darbuotojų ir gali gilintis jau ekspertiškai i ìvairius klausimus"). Kita vertus, pastebėtina ir tai, kad dalis parlamentarų gana kritiškai vertina vykdomosios valdžios jiems teikiamą informaciją. Ir ne tik todèl, kad informacijos tenka ilgai laukti („iš jų sunku kažka gauti arba labai viskas užtrunka ilgai'), bet ir todèl, kad pateikiama nepakankamai informacijos, ji yra tendencinga („ne visada ir nelabai greitai ministerijos pateikia, ko mums reikia, ir ta informacija, kuri ateina iš Vyriausybès kartu su ìstatymais, įstatymu projektais, aiškinamieji raštai, tai jinai yra tikrai ganètinai siaura, neatskleidžianti visų niuansų"). Galima pastebėti, kad pozicijoje esantys parlamentarai yra linkę teigiamiau vertinti vykdomąją valdžią kaip informacijos šaltini, o opozicijai priklausantys politikai vykdomosios valdžios teikiamos informacijos kokybę - kritiškiau.

Interesų grupès - dar vienas dažniau tiriamųjų minètų informacijos šaltinių sprendimų prièmimo kontekste. Tyrimas atskleidè, kad parlamentarai interesų grupes linkę traktuoti kaip alternatyvios informacijos šaltinius, galinčius pateikti įrodymus, argumentus, tyrimus, paramą rengiant įstatymų projektus. Kita vertus, tiriamieji linkę gana kritiškai vertinti interesų grupes kaip informacijos šaltinius dėl jų taikomų veiklos metodų. Tai atspindi šios tiriamųu mintys: „kai buvo tas kontroversiškas klausimas dèl skalūnų dujų <...> Tikrai ne visuomenininku rankomis, reiškias, yra užsakyti brangūs plakatai, stovintys, reiškias, autostradoj - tai yra akivaizdus verslo, kovojančio prieš tai, interesas“; „bandoma daryti įtaką, lobizmą geraja arba blogaja prasme“. 
Dar vienas iš dažniau tiriamųjų minètų šaltinių - rinkẻjai. Kadangi parlamentas yra Tautos atstovybė, Seimo nariai atstovauja rinkèjų ar rinkimų apygardų iškeltiems interesams ir siekia spręsti jų problemas: „vis tiek yra kažkokios tai problemos, kurios jau ateina iš žmoniu ir tu žinodamas ta problematika kažkaip formuoji savo matyma, savo sprendimus“; „apsisprendžiant dèl skalūnų dujų, tai man svarbiausia informacija buvo iš žmonių, kurie ten gyvena". Tačiau tiriamieji pastebi, kad tarp rinkejų yra „gana stiprus abejingumo laukas“ ir jie dažniausiai reaguoja ir tampa aktyvūs tik tuomet, kai politiniai sprendimai yra susiję su jais („didžioji dauguma rinkejjų, kaip ir interesu. grupés, reaguoja tik $i$ ju marškiniu problemas"). Iš rinkejjų gaunamą informaciją tiriamieji linkę vertinti skirtingai, vieni teigia, kad iš jų gaunama informacija aktuali ir patikima („kai žmogus praktiškai susiduria su problema, jis tau geriausia ir patikimiausia informacija gali pateikti"), kitas kalbintas politikas teigia, kad „retesnis rinkejjas gali pasiūlyti viena ar kita formulę teisés akto arba pateikti viena ar kita naudingesnę analitine informacija“"

Tyrimas atskleidè, kad, politikų vertinimu, politiniuose procesuose svarbus kaip informacijos šaltinio vaidmuo tenka žiniasklaidai. Žiniasklaidos kaip informacijos šaltinio privalumas, anot tiriamųjų, greitas informacijos pateikimas („tai tas kartais informacijos greitis yra bütinas todèl, kad būna labai apibrëžtas terminas, kada tu priimsi sprendima. $<\ldots>$ Kartais tokiais atvejais tenka pasikliauti ir žiniasklaidoj pasirodžiusia informacija“; „būna, sakykim, kažkokie rezonansiniai klausimai, kada kažkiek tai, matyt, iš anksto tau pradeda formuoti poziciją). Vienas tiriamasis pastebejo, kad „dalis parlamentaru per daug, man atrodo, pasitiki emociniais informacijos šaltiniais, ịskaitant ir mano minètus laikraščiu straipsnius“. Vis dèlto žiniasklaidos kaip informacijos šaltinio ịtakos priimant sprendimus remiantis atliktu tyrimu vienareikšmiškai ịvertinti negalima. Kai kurių tiriamųjų teigimu, žiniasklaida kaip informacijos šaltinis svarbesnis ne apsisprendžiant, kaip balsuoti, o atkreipiant dèmesi j $\mathfrak{i}$ tam tikras problemas, iškeliant aktualias temas 
(„atkreipia mano demesį $\mathfrak{i}$ atskirus karštus klausimus“; „viskuo tikèt, kq rašo žiniasklaida, negali“; „žiūri, kaip ta istatyma, projekta, pasiūlyma ir panašiai nušviečia žiniasklaida, nes tada matai, kaip tą tavo darbą suvoks rinkejjai"). Tyrimas rodo, kad dalis tiriamųjų linkę gana kritiškai vertinti žiniasklaidos kaip informacijos šaltinio patikimumą („patikimumo problema aktuali net aukščiausio lygio žiniasklaidoje“; „didele dalis spaudos pas mus labai tendencinga, labai šališka“; „kai kalbam apie žiniasklaidos informacija, dažnai pasiklystame tikrume").

Komitetus, kurie formuojami vadovaujantis specializacijos principais, parlamentarai vertina kaip vienus iš reikšmingiausių informacijos šaltinių. Vienu iš šio informacijos šaltinio privalumų ịvardijama kompetencija („,vis tiek ten ị klausima būna įsigilinama daugiau, plius dirba geri, kompetentingi specialistai“; „turintys patirties ir žiniu žmonès dirba“; „isiklausome i to komiteto nuomonę), „nepolitizavimas“ („komitetų informacijoje nèra nereikalingo politizavimo"), detalus sprendimo išnagrinejjimas ir išsamios informacijos surinkimas („detaliai išnagrinejja projektus ir surenka kiek ịmanoma visapusiškesnę informacija“; „komitete galima ǐ̌girsti išsamias ir argumentuotas diskusijas“; „ekspertiniai ir informaciniai ištekliai geriausi sutelkti komitetuose").

Vienas iš dažniausiai parlamentarų minètų informacijos šaltinių - Seimo kanceliarijos Parlamentinių tyrimų departamentas, kuris laikomas patikimu informacijos šaltiniu („man yra patikima vis tiktai Parlamentiniu tyrimy departamento informacija“; „aš jais pasitikiu, nes man atrodo, kad jie ten nešališkai ir išsamiai tą informacija surenka"), pateikiantis išsamią analitinę informaciją („tai kanalas gauti iš esmès išsamiausią analitinę informacija“; „jeigu jau reikia kokios rimtos analizès, kreipiesi i Parlamentiniu tyrimu departamenta“), „nepolitikuojantis“ („nera ten jokio politikavimo“). Tačiau kai kurie parlamentarai atkreipia dèmesị, kad šio departamento informaciją dažniau naudoja rengdami įstatymų pasiūlymus, o ne priimdami sprendimus („dažniau naudoji inicijuojant projektą, <..> o priimant sprendimus nelabai, nes reikia ilgai laukti iš jų informacijos"). Kitas tiriamasis atkreipé dèmesị, kad dalis informacijos, kurią teikia šis departamentas, 
nèra naudinga tiesioginiam jų darbui („Parlamentiniu tyrimų departamentas daugiausia teikia tas žiniasklaidos apžvalgas, tai jomis pasinaudot gali $<\ldots>$ savo i̊domumui $<\ldots>$, bet tai tikrai nèra tai, kas tiesiogiai turèty büt susiję su mūsu kasdieniniu darbu ar sprendimu priemimu").

Kitas parlamentarų išskirtas informacijos šaltinis - asmeniniai patarèjai. Nors dalis parlamentarų teigè, kad turi patarejų, kurie atlieka svarbų vaidmenị padèdami rengti įstatymų projektus, asmeninius patarejus parlamentarai vis dèlto labiau linkę vertinti kaip informacijos tarpininkus, atliekančius „techninị darbą“, „,informacijos laidininkus“, „papildomas rankas ieškant informacijos", o ne informacijos vertintojus, analitikus ar nuomonès formuotojus („aš pasakau: reikia čia pažiūrèti, čia, čia, ir jie tada jau ta, sakysim, technini darbq atlieka“; "padejejai yra mano papildomos rankos susirankiot informacija, o nuomonès formuotojas esu aš"; „padejejjai tiesiog tiktai padeda susirinkt informaciją. <...> Laidininkas kažkoks tai`).

Internetas - vienas iš dažniausiai politikų minètų informacijos šaltinių ir yra traktuojamas kaip įrankis informacijai rasti. Pagrindinis šio informacijos šaltinio privalumas - prieinamumas ir galimybė gauti informaciją greitai („jeigu aš ieškau, tai aš ieškau jau internete, jau neinu i bibliotekg ir neieškau archyvuose, tiek laiko nerra“; „jeigu informacijos reikia greitai, naudojiesi Google").

Parlamentarai teigia, kad mokslinių ir analitinių institucijų teikiama informacija taip pat yra svarbi („globaliniais klausimais, kaip dèl skalūnu dujų, pavyzdžiui, kur yra labai rezonansiniai klausimai, tai dažnokai naudojamès specialistu, ekspertu, mokslininku išvadomis"). Tačiau tiriamieji pabrèžia, kad dèl laiko trūkumo („iš mokslininkų dažniausiai negausi informacijos nei per diena, nei per dvi, o kartais net per dvi savaites"), dèl sprendimų priemimo skubos ir ypatingos skubos tvarka, mokslininkų ar tyrimų centrų proaktyvios kaip informacijos šaltinio veiklos trūkumo ar menko suinteresuotumo („iš tikruju tai mokslo institucijos labai pasyviai isitraukia i ìstatymu leidybą, nebent tai juos labai tiesiogiai paliečia“; „jeigu ju neįtrauki, tai jie patys nelabai rodo iniciatyvos") jų potencialas yra menkai išnaudojamas. 
Jeigu sprendimui priimti skiriama daugiau laiko, parlamentarai linkę naudotis daugiau ir įvairesniais informacijos šaltiniais ir priešingai - kuo mažiau laiko turima sprendimui priimti, tuo labiau linkstama naudotis mažiau ir lengviau prieinamais informacijos šaltiniais.

Gaunamos informacijos vertinimas ir naudojimas priimant sprendimus. Tyrimas atskleidè, kokios yra svarbiausios informacijos savybès, atitinkančios parlamentarų lūkesčius ir reikalavimus. Didžioji dalis tiriamụjų akcentavo neturintys pakankamai laiko ir galimybių įsigilinti į visą gaunamą informaciją, todèl prioritetai teikiami tam tikrai informacijai. 6 lenteleje išskirtos 8 kategorijos - informacijos kokybès charakteristikos parlamentarų požiūriu.

6 lentele. Informacijos kokybès charakteristikos parlamentaru požiūriu

\begin{tabular}{|c|}
\hline Kategorija \\
\hline Patikimumas \\
\hline Tinkamas informacijos kiekis \\
\hline Pateikimo glaustumas \\
\hline Informacijos prieinamumas ir gavimas laiku \\
\hline Šaltinio žinomumas / artumas \\
\hline Reputacija \\
\hline Aktualumas ir pritaikomumas \\
\hline Tikslumas \\
\hline
\end{tabular}

Tyrimas rodo, jog dažniausiai parlamentarai pageidauja, kad informacija būtų glausta, koncentruota ir pateikiamas tinkamas duomenų kiekis. Jeigu informacijos per daug, dalis apklaustųjų nurodė, kad tuomet informaciją jie linkę ignoruoti ir atmesti, nors ji potencialiai galbūt galètų duoti naudos („svarbiausia, kad kalbètu ir rašytų i temą“; „esmè turi tilpti i viena puslapi, jeigu daugiau, aš tą informaciją dedu i šalį“; „jeigu matau, kad informacijos daug ir joje pilna išvedžiojimu ne į temą, aš jos paprasčiausiai neskaitau"). Tyrimas atskleidè, kad vienas iš svarbiausių informacijos vertès 
kriterijų yra informacijos ir jos šaltinio patikimumas („man svarbiausia, kad informacija būtu patikima“; „jeigu tai patikimas šaltinis, aišku, kad aš tada informacija skaitau"). Tiriamieji taip pat akcentavo šaltinio, iš kurio gauna informaciją, žinomumą ir artimumą („labiau linkęs pasitikèti tais žmonem, kurie su tavim dirba, <...> tas artimiausias, kaip sakoma, bendradarbiu ratas“; „naudojuosi patirtimi ir tais žmonèmis, kuriuos pažistu ir žinau"). Dar vienas politikų dažniau minètas informacijos kokybès kriterijų yra reputacija („jeigu turi reputacija bent jau mano akyse“; „net jeigu informacija neatitinka mano ideologiniu pažiürų, bet yra iš rimtos analitinès organizacijos ar analitinio centro, aš su ja stengiuosi susipažinti ‘). Tiriamieji taip pat akcentavo informacijos tikslumą („aš teikiu pirmenybę faktams, o išvadas ir politinius sprendimus pasidarau aš pati“; „tai patikimiausi, sakyčiau, vis tiek yra faktologiniai kažkokie duomenys“; „statistika tiksliausia“), taip pat informacijos suprantamumą („Seimo nariai nèra visu sričiu ekspertai, todè informacija, ypač iš įstatymu teikèju, turètų ateiti suprantamai ir aiškiai pateikta“; „kartais surašo tokia sudètinga biurokratine, technine kalba, kad neįmanoma ne tik suprasti, bet ir skaityti"). Apklaustieji pabrèžè, kad priimant sprendimus labai svarbu informacijos gavimas ir pateikimas laiku („svarbiausia nepavéluotai gauti informacija“).

Tiriamieji linkę vertinti informaciją, kuri yra politiškai aktuali ir pritaikoma, pavyzdžiui, apie sprendimų pasekmes ir jų galimą poveikị rinkejjams („aš parlamento sprendimus turiu pristatyti rinkejjams"). Politikai linkę naudoti tą informaciją, kuri jiems leidžia pagrịsti jų ideologinę poziciją, nuostatas, nuomonę. Tą patvirtina tokie tiriamųjų samprotavimai: „Štai ko mums trūksta - pažiūrèti, kokie yra bendri tikslai ir žiūrèti, kaip tuos bendrus tikslus pasiekt, o ne išryškinti savo skirtumq nuo oponento ir tada ta savo pozicija ginti; tai man atrodo iš principo ganètinai neproduktyvus požiūris, tačiau tokia sprendimu priemimo kultūra pas mus vyrauja“; „jeigu žinai, kad tam tikri subjektai, pretenduojantys dažnai i tą ekspertine nuomonę, turi tą ideologini pamušala aišku, tai aš paprastai i juos žiūriu rezervuotai“; „,atstovauju ir tam tikrai savo ideologinei mokyklai-socialinei, ekonominei, psichologinei, filosofinei ir istorinei mokyklai; aš negaliu sutikti 
su liberalo siūlomais receptais arba su konservatoriaus siūlymais“. Kai kurių tiriamųjų nuomone, net ir turint daugiau informacijos, jų nuomonè ar pozicija priimant sprendimus nesikeistų. Tai iš tiesų leidžia daryti prielaidą, kad informacija politiniuose sprendimuose dažnai igyja simbolinị vaidmenį, naudojama kaip įrankis siekiant parodyti sprendimų prièmimo legitimumą ir demokratiškumą. Tokias prielaidas leidžia daryti šios politikų išsakytos mintys: „Aš manau, kad taip, mes galetume turèti daugiau informacijos, bet ar tai pakeistų mano sprendimą? Turbūt labai retai. Tik aš büčiau tikresnis dèl to sprendimo".

Informacijos, susijusios su sprendimų prièmimu, sklaida ir aprūpinimo informacija tobulinimo poreikis parlamentarų požiūriu. Respondentų požiūris ị informacijos sklaidą parlamento institucijoje ir informacinị aprūpinimą gana išsiskyrè. Vieni politikai tvirtina, kad juos iš esmès tenkina institucijos informacijos sklaida ir gaunama informacija („,informacijos laukas yra praktiškai beribis, todel jeigu kas nors ir galètu manęs netenkinti, tai tiktai mano paties noras ta informacija naudotis ir ja sisteminti"), kiti respondentai atkreipe dèmesi $\mathfrak{i}$ tam tikrus informacijos sklaidos trūkumus ir poreikị tobulinti informacinị aprūpinimą. Kokybiškai analizuojant tyrimo duomenis buvo išskirtos 8 kokybinès kategorijos, susijusios su parlamentarų informavimo ir informacinio aprūpinimo tobulinimo poreikiu (7 lentelè).

\section{7 lentele. Parlamentaru informavimo ir informacinio aprūpinimo} tobulinimas

\begin{tabular}{|c|}
\hline Kategorija \\
\hline Informacijos gavimas laiku \\
\hline $\begin{array}{c}\text { Informacinis aprūpinimas priimant ịstatymus skubos arba ypatingos } \\
\text { skubos tvarka }\end{array}$ \\
\hline Personalo trūkumas ir kvalifikacija \\
\hline Proaktyvios informacijos sklaidos institucijoje poreikis \\
\hline Informacijos perteklius \\
\hline Informacijos aktualumas ir tinkamumas \\
\hline Informacijos vienpusiškumas \\
\hline Sprendimų prièmimo proceso tobulinimo poreikis \\
\hline
\end{tabular}


Duomenų analizė rodo, kad parlamentarai linkę priekaištauti, jog informaciją gauti užtrunka per daug laiko arba ji pasiekia pavèluotai, ypač tuomet, kai sprendimai priimami skubos arba ypatingos skubos tvarka („reikia pasiruošti, kad ne anksčiau kaip po triju keturiu savaičiu mes gausim ta informacija ir kartais jau mums jinai ateina paveluotai“; „tos informacijos, kurios norètum ir kurios tau reikètu, tu nespejji susirinkti ar tau nespeja pateikti“; „sprendimas dažnai praeina pirma negu gauni tą analizę"). Viena vertus, parlamentarai pastebi, kad jie susiduria su gaunamos informacijos pertekliaus problema ir pripažįsta neturintys pakankamai laiko išanalizuoti gaunamą informaciją, kita vertus, jie nurodo, kad aktualios bei tinkamos informacijos priimant sprendimus trūksta („pavyzdžiui, skalūnu gavybos klausimais mums informacijos labai labai trūko“; „su trūkumu tikrai dažnai arba tokiu neadekvačiu pateikimu“; „dažnai Seimas turi pakankamai maža informacijos srautą). Už informacinị aprūpinimą atsakingi parlamento padaliniai kritikuojami dèl nepakankamos proaktyvios informacijos sklaidos („galétumèm laukti ju didesnès iniciatyvos“; "yra tas informacijos platinimas, jeigu kažkuris Seimo narys paprašo ar frakcija paprašo, kad išplatintu, bet to per mažai“; "turètu patys tiesiog persiųst automatiškai visa informacija, <...> nes pas juos ten krūva tos informacijos surinkta, bet jeigu niekas nesikreipè, tai maždaug jie tyli ir niekam nieko"). Kai kurie tiriamieji išsakè nuomonę dèl vienpusiškos informacijos pateikimo, dažniausiai iš vykdomosios valdžios institucijų, nenurodant visų galimų sprendimo pasekmių, kitų alternatyvų („ko gero, blogiausia situacija yra su Europos Sajungos nuostatu diegimu“; „kartais yra, kada po pagrindiniais postulatais dar yra ịvairiu kitu įdèta niuansu, kuriu, pavyzdžiui, Vyriausybe labai viešai nenori atskleisti ir deklaruot“; „informacija yra tendencinga ir tokia, kokia palanki valdančiajai daugumai"). Kai kurie tiriamieji atkreipé dèmesị i silpną patarejjų - tiek parlamentarų asmeninių, tiek frakcijų - pasirengimą atlikti jiems reikalingą analitinị su informacija susijusị darbą bei asmeninio personalo trūkumą. Tokias nuostatas atskleidžia parlamentarų samprotavimai: „nelaimé ta, 
kad tu patarëju finansinis aprūpinimas yra toks, kad aš teisininko arba ekonomisto, gero profesoriaus paimt ị patarèjus negaliu, nes aš jam nepasiūlysiu tūkstančio aštuonių šimtų atlyginimo“; „sekretoriatai, frakcijų padejejai ir partiju politiniai organai neatlieka savo darbo. (Klausimas: Kuria prasme neatlieka?) Analitine“; „apart geros technikos, kuriq jūs čia matot, iš tikro intelektualiniu resursu nèra“. Parlamentarai pastebejo, kad informavimo ir informacinio aprūpinimo problemas galima būtų išspręsti tobulinant sprendimų prièmimo procesą. Vienas iš kai kurių politikų pateiktų siūlymų - apriboti pavienių Seimo narių teises teikti isstatymų projektus ar jų pataisas, tik tam tikrais atvejais suteikti teisę priimti įstatymus skubos ar ypatingos skubos tvarka.

\section{Išvados}

Kokybinis tyrimas atskleide, kad parlamente priimamiems sprendimams dažnai būdingas politinis sprendimų prièmimo pobūdis, kuris lemia tam tikrus parlamentarų informacinès elgsenos ypatumus. Nors politiniuose sprendimuose parlamentarai informacijai dažnai linkę suteikti „esminį“, „kertinị“, „svarbiausią“ vaidmenị, analizuojant realias sprendimų prièmimų situacijas išryškejo, kad dažnai informacijos ieška yra negili ir paviršutiniška, naudojamasi lengviau ir greičiau prieinamais informacijos šaltiniais, pavyzdžiui, frakcijos / partijos kolegomis, o sprendimai priimami naudojant tam tikras supaprastinimo strategijas, pavyzdžiui, remiantis partijos suformuota pozicija, programinėmis nuostatomis, taip pat apsisprendimus nulemia frakcijos drausmès taisyklès.

Tyrimas atskleidè, kad priimant politinius sprendimus būdingas šališkas informacijos naudojimas, kai informacija pasitelkiama ir naudojama argumentams pateisinti ar pozicijai pagrịsti, o ne galimoms sprendimo alternatyvoms ir pasekmėms įvertinti. Ne visa informacija sprendimų prièmejų yra vienodai vertinama ir naudojama. Politikai linkę naudoti informaciją, kuri atitinka jų lūkesčius ir reikalavimus, 
pavyzdžiui, yra gaunama iš patikimo šaltinio, yra glausta, koncentruota ir pateikiamas tinkamas duomenų kiekis, gaunama iš informacijos šaltinio, kuris yra artimesnis ir žinomesnis. Jeigu informacijos per daug, politikai ją linkę ignoruoti ir atmesti, nors tai potencialiai galbūt galètų būti naudinga informacija.

Nors parlamento nariai teigè neturintys pakankamai laiko ir galimybių ịsigilinti $\mathfrak{i}$ visą gaunamą informaciją, jie išreiške poreiki gauti dar daugiau informacijos. Tai liudija apie galimą simbolinị informacijos vaidmeni priimant politinius sprendimus, kai informacijos gavimas ir turejimas yra svarbiau nei realus jos panaudojimas. Tokiu atveju informacija tampa simboliniu įrankiu siekiant „racionalizuoti“ politinius sprendimus, užtikrinti parlamente priimamų sprendimų teisètumą.

Lietuvos Respublikos Seimo narių informacinès elgsenos tyrimas atskleide, kad parlamentaro kaip informacijos vartotojo elgsena priklauso nuo priimamo sprendimo svarbos suvokimo, kuo sprendimas suvokiamas kaip svarbesnis ir aktualesnis, tuo labiau politikas yra motyvuotas ieškoti informacijos, ją gauti ir analizuoti. Politikai linkę vengti daug laiko ir kitų išteklių reikalaujančios informacijos ieškos, kol nekyla poreikis gauti informacijos iškilus tam tikroms "probleminėms“ situacijoms, kurios dažniausiai sietinos su sprendimais, keliančiais tam tikrą rezonansą, sulaukiančiais didelio visuomenès, žiniasklaidos, pačių politikų ar kitų grupių dèmesio, kontroversiškais ir prieštaringais sprendimais. Kitas svarbus veiksnys, lemiantis parlamentarų informacinę elgseną, yra parlamento nario vaidmuo - jo užimamos pareigos ir specializacija.

Tyrimas leido įvertinti Seimo narių požiūrị ị informacijos sklaidą parlamente ir informacinị aprūpinimą bei numatyti galimybes tobulinti sprendimų prièmimo proceso informacinị aprūpinimą. Seimo nariai iš esmès teigiamai vertina informacinị aprūpinimą vykdančių Seimo kanceliarijos struktūrų darbą ir palankiai vertina skleidžiamos informacijos patikimumą, išsamumą, aktualumą. Tačiau akcentuota ir tai, kad informacinis aprūpinimas yra nepakankamas, pavyzdžiui, dažnai 
nèra galimybių priimant ịstatymus skubos ar ypatingos skubos tvarka greitai gauti norimą analitinę / ekspertinę informaciją iš parlamentinių informacijos šaltinių. Tyrimas atskleidè, kad ne visa teikiama informacija yra vienodai aktuali ir svarbi parlamentarams kaip ịstatymų leidèjams ir sprendimų prièmėjams, todèl vykdant informacinį aprūpinimą reikètų teikti prioritetą toms paslaugoms ir informacijos produktams, kurių poreikis parlamentarams yra didžiausias, pavyzdžiui, analitiniai tyrimai. Parlamentarų požiūriu, dèl didelio skubos ir ypatingos skubos tvarka priimamų ịstatymų skaičiaus jie ne visada gauna informaciją laiku, todèl būtina siekti užtikrinti operatyvų aprūpinimą informacija. Tyrimas atskleidè proaktyvaus informacinio aprūpinimo parlamente poreikị - už informacinị aprūpinimą atsakingos parlamento struktūros turètų daugiau savo iniciatyva teikti informacijos, susijusios su parlamente svarstomais ir priimamais sprendimais. Turètų būti siekiama maksimaliai užtikrinti pačių informacijos vartotojų prieigą prie parlamento institucijoje sukauptų ir kitų naudingų informacijos išteklių, o informacija politikus aprūpinančių struktūrų darbą orientuoti į efektyvesnị didesnès pridètinès vertès - ekspertinių ir analitinių - informacinių produktų kūrimą. Kai kurie politikai nurodè nepakankamai žinantys apie egzistuojančią informacinio aprūpinimo sistemą, pavyzdžiui, parlamentinès bibliotekos jiems teikiamas individualizuotas paslaugas, todèl kyla parlamentarų ir jų asmeninio personalo mokymų poreikis. Tyrimas taip pat atskleidè parlamentarų asmeninio personalo trūkumo ir nepakankamos kvalifikacijos aprūpinant politikus sprendimams reikalinga informacija problemas. 


\title{
INFORMATION BEHAVIOR OF MEMBERS OF THE PARLIAMENT: THE CASE OF THE MEMBERS OF THE SEIMAS
}

\author{
Aurelija Vernickaité
}

\section{Summary}

Keywords: information behavior; information seeking; provision of information; parliament; legislators; decision making; legislation.

Decision making is considered as one of the main activities of legislators. Information is seen as crucial part of decision making. Although in many theories of decision making the role of information is differently conceptualized and interpreted, however significance of information in decision making process is undeniable. Therefore information behavior of legislators requires exclusive and comprehensive scientific analysis. In this article results of empirical study is presented. Semi-structured interviews were carried out with a total 19 legislators. The study explores the importance of information in political decisions from legislators' view, reveals the factors which motivates legislators to seek information, the importance of different information sources and how information is used in decision making. Findings of the study show that legislators face the problem of too many decisions and too little time, so frequently they tend to perfunctory information search and tend to rely on colleagues, follow their political group (party) position or political programme as they make decisions. Most often legislators engage in an comprehensive information search only when confront with an unusual or problemistic situation, for example a controversial or conflicting issue.

Iteikta 2013 m. gruodžio 19 d. 